九州大学学術情報リポジトリ

Kyushu University Institutional Repository

\title{
Use of Elemental Fingerprint Analys is to Identify Localities of Collection for the Large Icefish Protosalanx chinensis in Taihu Lake, China
}

Ye, Shanshan

Wuxi Fisheries College, Nanjing Agricultural University | Key Laboratory of Ecological Environment and Resources of Inland Fisheries, Freshwater Fisheries Research Center, Chinese Academy of Fishery Sciences

Yang, Jian

Wuxi Fisheries College, Nanjing Agricultural University | Key Laboratory of Ecological Environment and Resources of Inland Fisheries, Freshwater Fisheries Research Center, Chinese Academy of Fishery Sciences

Liu, Hongbo

Key Laboratory of Ecological Environment and Resources of Inland Fisheries, Freshwater Fisheries Research Center, Chinese Academy of Fishery Sciences

Oshima, Yuji

Division of Bioscience and Biotechnology, Graduate School of Bioresource and Bioenvironmental Sciences, Kyushu University

https://doi.org/10.5109/19634

出版情報: 九州大学大学院農学研究院紀要. 56 (1)，pp.41-45, 2011-02. Faculty of Agriculture, Kyushu University

バージョン :

権利関係 : 


\title{
Use of Elemental Fingerprint Analysis to Identify Localities of Collection for the Large Icefish Protosalanx chinensis in Taihu Lake, China
}

\author{
Shanshan YE ${ }^{1,2}$, Jian YANG ${ }^{1,2 *}$, Hongbo LIU $^{2}$ and Yuji OSHIMA ${ }^{3}$ \\ ${ }^{1}$ Wuxi Fisheries College, Nanjing Agricultural University, Jiangsu Wuxi 214081, China \\ ${ }^{2}$ Key Laboratory of Ecological Environment and Resources of Inland Fisheries, Freshwater Fisheries Research Center, \\ Chinese Academy of Fishery Sciences, Jiangsu Wuxi 214081, China \\ ${ }^{3}$ Division of Bioscience and Biotechnology, Graduate School of Bioresource and Bioenvironmental Sciences, \\ Kyushu University, Hakozaki 6-10-1, Higashi-ku, Fukuoka 812-8581, Japan \\ (Received October 26, 2010 and accepted November 8, 2010)
}

\begin{abstract}
Concentrations of eighteen major and trace elements; $\mathrm{Na}, \mathrm{Mg}, \mathrm{Al}, \mathrm{K}, \mathrm{Ca}, \mathrm{Cr}, \mathrm{Mn}, \mathrm{Fe}, \mathrm{Co}, \mathrm{Ni}, \mathrm{Cu}, \mathrm{Zn}, \mathrm{As}$, $\mathrm{Se}, \mathrm{Mo}, \mathrm{Ag}, \mathrm{Tl}$, and $\mathrm{Pb}$ were studied in the large icefish Protosalanx chinensis collected from four sampling areas (Yixingtan, Jiaoshan, Pingtaishan and Sanshandao) in Taihu Lake, China. This species was rich in essential elements (e.g., $\mathrm{Na}, \mathrm{Mg}, \mathrm{K}, \mathrm{Ca}, \mathrm{Zn}$ ) and was uncontaminated with potentially toxic elements (e.g., $\mathrm{As}, \mathrm{Ag}$, and $\mathrm{Pb}$ ). Iron levels were lower than expected. Concentrations of $\mathrm{Mg}, \mathrm{Al}, \mathrm{K}, \mathrm{Ca}, \mathrm{Mn}, \mathrm{Cu}, \mathrm{Zn}$ and $\mathrm{Se}$ in $P$. chinensis showed significant differences $(\mathrm{P}<0.05)$ among sampling areas, clearly revealed by principal component analysis. Moreover, the origin of $P$. chinensis specimens from these four areas of Taihu Lake, discerned by multivariate statistical analyses, was characterized consistently by elemental fingerprint analysis (EFA). The EFA method has broad potential to identify source populations of species and fishery products in the marketplace.
\end{abstract}

\section{INTRODUCTION}

Icefishes (Salangidae) are mostly distributed in eastern Asia, and fifteen of the 17 global icefish species live in China's coastal area, outflow rivers and estuaries; six are endemic to China (Xie and Xie, 1997). Taihu Lake $\left(119^{\circ} 54^{\prime}-120^{\circ} 36^{\prime} \mathrm{N}, 30^{\circ} 56^{\prime}-31^{\circ} 33^{\prime} \mathrm{E}\right)$ is the third largest freshwater lake in China and is located in southern part of Jiangsu Province, playing a vital role in water supply, agriculture, and fisheries. Icefish species residing in Taihu Lake include Hemisalanx brachyrostralis, Neosalanx oligodontis, $N$. taihuensis and especially Protosalanx chinensis. The large icefish $P$. chinensis is an economically important but small species of the Salangidae. Despite its small body size, $P$. chinensis is highly nutritious and of dietary importance for residents around Taihu Lake, as well as for commercial export. With the rapidly growing demand for P. chinensis, consumer markets have shown greater interest in information on the geographical origin of catches, due to different market qualities. Recently, exploratory research has been conducted successfully to identify the geographical origin of agricultural products with elemental fingerprint analysis (EFA) at home and abroad. Foods successfully tested include dairy products (Pillonel et al., 2003), honey (Nalda et al., 2005), grape wine (Galgano et al., 2008), meat (Renou et al., 2004), beverage materials (Marcos et al., 1998), and cereal (Branch et al., 2003). Physicochemical parameters also are stable over a long period of time and can be used as environmental indicators (Nalda et al., 2005). However, there are few reports on the application of EFA in the origin of fishery products traceable worldwide. Recently, Japanese researchers reported that distinct regional profiles of trace element content in tis-

* Corresponding author (E-mail: jiany@ffrc.cn) sues of the Japanese eel and littleneck clam can be used to identify their origin from Japan or as imported from China or Korea (Yamashita et al., 2006; Yamashita et al., 2008). A recent study in our laboratory also suggested that pattern recognition of multi-element concentrations in $P$. chinensis can be used to determine their geographic origin from Taihu Lake or Hongze Lake (300 km away from the Taihu Lake) (Yang et al., 2009). To further apply EFA and establish its limits of utility, we tested whether EFA could be used to identify the geographic origin of fish from different areas of the same inland lake. Therefore in this study, the elemental characteristics (elemental fingerprints) in icefishes ( $P$. chinensis) from four different areas of Taihu Lake were investigated in detail by inductively coupled plasma mass spectrometry (ICP-MS). The feasibility of utilizing EFA was assessed by determining whether the origin of collection could be discerned correctly for this species by chemometric multivariate analyses.

\section{MATERIALS AND METHODS}

The large icefishes were collected in May 2005 from four different areas (Yixingtan, Jiaoshan, Pingtaishan and Sanshandao) of Taihu Lake (Fig. 1). Because P. chinensis is a small species, we selected 15 individuals of similar size from those collected in each sampling area, and randomly divided them into 5 analytical samples, with 3 individuals per sample (Table 1). The resultant 20 samples were carefully rinsed six times with Milli-Q water (Millipore Corp., USA, with resistivity: $18.2 \mathrm{M} \Omega \cdot \mathrm{CM}$ ), and then dried for $24 \mathrm{~h}$ at $80^{\circ} \mathrm{C}$ to a constant weight. After recording the moisture content, we ground the samples into fine powder. All samples were placed immediately into a desiccator prior to analysis.

Each dry sample, $0.1 \pm 0.005 \mathrm{~g}$, was placed into a 


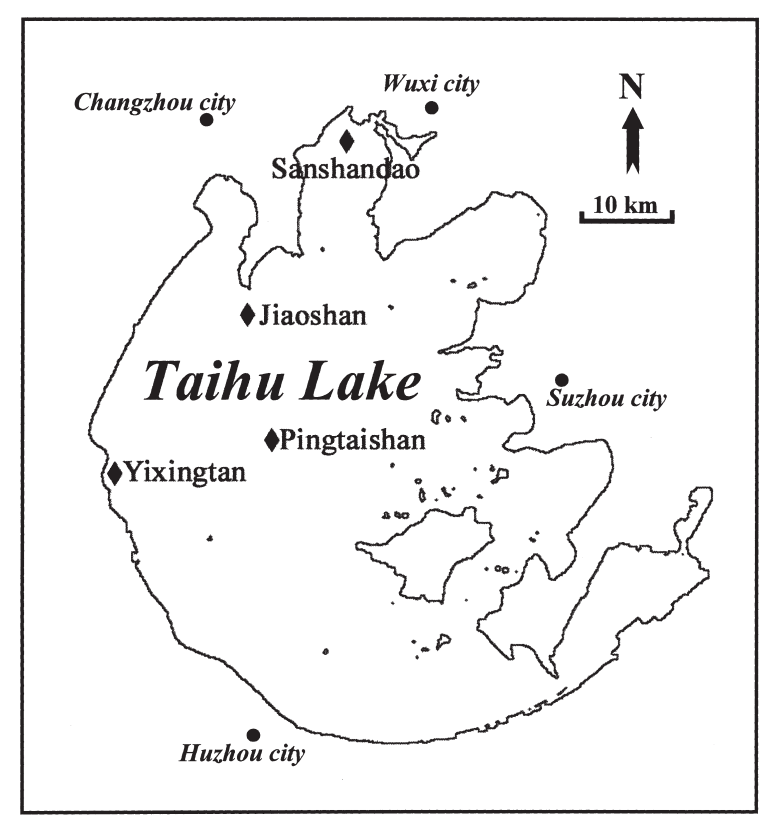

Fig. 1. Location of the sampling areas( ) in Taihu Lake, China.

Table 1. Metrics of the icefish Protosalanx chinensis collected at four areas in Taihu Lake, China

\begin{tabular}{lcccc}
\hline Sampling areas & $N$ & Body length $(\mathrm{cm})$ & & Body wet weight (g) \\
\cline { 5 - 5 } Yixingtan & 15 & $6.8 \pm 0.4$ & & $0.5 \pm 0.1$ \\
Jiaoshan & 15 & $6.4 \pm 0.3$ & & $0.7 \pm 0.2$ \\
Pingtaishan & 15 & $6.4 \pm 0.3$ & & $0.6 \pm 0.1$ \\
Sanshansao & 15 & $6.4 \pm 0.4$ & & $0.6 \pm 0.1$ \\
\hline
\end{tabular}

digestion tube, and $10 \mathrm{~mL}$ of purified $\mathrm{HNO}_{3}$ (MOS reagent, Sinopharm Chemical Reagent Co., Ltd., China) was added. Then, all the samples were digested using a microwave digestion system (ETHOS A T260, Milestone Inc., Italy), and the resultant solutions were diluted to $200 \mathrm{~mL}$ with Milli-Q water. An Agilent 7500ce ICP-MS was used to measure concentrations of 18 chemical elements; $\mathrm{Na}$, $\mathrm{Mg}, \mathrm{Al}, \mathrm{K}, \mathrm{Ca}, \mathrm{Cr}, \mathrm{Mn}, \mathrm{Fe}, \mathrm{Co}, \mathrm{Ni}, \mathrm{Cu}, \mathrm{Zn}, \mathrm{As}, \mathrm{Se}, \mathrm{Mo}, \mathrm{Ag}$, $\mathrm{Tl}$, and $\mathrm{Pb}$. Quality assurance and quality control was checked by spike recoveries (80\%-120\%). All concentration data were expressed on a dry-weight basis, except for those specially marked. Statistical analyses were performed using the program SPSS V16.0 (SPSS Inc., USA).

\section{RESULTS AND DISCUSSION}

Concentrations of the 18 chemical elements from four areas of Taihu Lake are summarized in Table 2. As expected, the concentration values of essential elements $\mathrm{Ca}, \mathrm{K}, \mathrm{Na}, \mathrm{Mg}$, and $\mathrm{Zn}$ were high, that of $\mathrm{Al}$ was moderate, and those of $\mathrm{Mn}, \mathrm{Cu}$, Se were low. In addition, concentration values of $\mathrm{Fe}, \mathrm{Co}, \mathrm{Ni}, \mathrm{As}, \mathrm{Mo}, \mathrm{Ag}, \mathrm{Tl}, \mathrm{Pb}$ in all samples, and $\mathrm{Cu}$ and $\mathrm{Cr}$ in some samples, were lower than the limit of detection. It is evident that these icefishes were not contaminated with the potentially toxic elements As, Ag, and Pb. Moreover in our previous study, P. chinensis from Hongze Lake and the Gonghu area of Taihu Lake also had high concentrations of Ca, K, Na, Mg, and Zn, but lacked Fe (Yang et al., 2009). Therefore, the present study highlights that $P$. chinensis, an important food source around Taihu Lake, contributes essential minerals as a food source but is of low nutritional value for dietary Fe.

The extremely low concentration of Fe, a vital micronutrient, was unexpected. Iron has an active role in oxidation/reduction reactions and electron transport associated with cellular respiration (Watanabe et al., 1997; Bury and Grosell, 2003). Iron deficiency results in anemia and poor egg-hatching rate in fish (Watanabe et al., 1997). Low Fe values suggest that this element plays a very minor physiological role in $P$. chinensis, even during respiration. At present, no reports are available on the respiratory mechanism of $P$. chinensis or in other salangid fishes. As alternatives, $\mathrm{Cu}$ and $\mathrm{Mn}$ can participate in the respiratory function of certain aquatic animals, rather than Fe. Copper is a component of the respiratory pigment haemocyanin in molluscs and arthropods (Terwilliger, 1998), whereas manganese is believed to be involved in oxygen transportation in the Antarctic icefish Champsocephalus gunnari (Ishikawa and Nakamura, 1990). Concentrations of $\mathrm{Mn}$ in $P$. chinensis of this study and that of Yang et al. (2009) is much higher than those of $\mathrm{Cu}$ and $\mathrm{Fe}$, suggesting that Mn may play a role similar to that determined for Champsocephalus gunnari. Further studies are necessary to understand the possible significance of Mn on the physiological mechanisms (especially respiration) of $P$. chinensis.

The spatial differences of $\mathrm{Na}, \mathrm{Mg}, \mathrm{Al}, \mathrm{K}, \mathrm{Ca}, \mathrm{Cr}, \mathrm{Mn}$, $\mathrm{Cu}, \mathrm{Zn}$, and Se concentrations in $P$. chinensis from the four areas in Taihu Lake was investigated statistically (Table 3). The elements Fe, Co, Ni, As, Mo, Ag, Tl, and $\mathrm{Pb}$ were excluded from analysis because they were below detection levels. The levels of $\mathrm{Na}$ and $\mathrm{Cr}$ did not show any significant difference $(\mathrm{P}>0.05)$ among the four areas in Taihu Lake. However, the concentrations in $P$. chinensis were seldom similar to each other. For example, $\mathrm{Ca}, \mathrm{Mn}$, and $\mathrm{Cu}$ concentrations were significantly higher $(P<0.01)$ in $P$. chinensis from the Yixingtan area, whereas $\mathrm{Mg}, \mathrm{Al}, \mathrm{Cu}$ concentrations were significantly lower $(P<0.01)$ in those from the Sanshandao area than from the other areas (Table 3). Elemental concentrations in icefishes tended to differ among the four areas in Taihu Lake, perhaps reflecting slight regional differences in water chemistry or food availability.

A multi-element accumulation profile is likely influenced by the background concentration of elements. Principal components analysis (PCA) of the spatiallyfish from different elements was conducted on concentrations of $\mathrm{Mg}, \mathrm{Al}, \mathrm{K}, \mathrm{Ca}, \mathrm{Mn}, \mathrm{Cu}, \mathrm{Zn}$, and Se to assess the elemental concentrations in fish from each area. It is noteworthy that $P$. chinensis from the four sampling areas were distinctly separate without overlap (Fig. 2). The elements $\mathrm{Mg}, \mathrm{Al}, \mathrm{Ca}, \mathrm{Mn}, \mathrm{Cu}$ and $\mathrm{Zn}$ dominated prin- 
Table 2. The concentration of elements (mg/kg) in Protosalanx chinensis collected from four areas in Taihu Lake, China

\begin{tabular}{|c|c|c|c|c|c|c|c|c|c|c|c|}
\hline $\begin{array}{l}\text { Sampling } \\
\text { areas }\end{array}$ & $\begin{array}{c}\text { Sample } \\
\text { name }\end{array}$ & $\mathrm{Na}$ & $\mathrm{Mg}$ & $\mathrm{Al}$ & $\mathrm{K}$ & $\mathrm{Ca}$ & $\mathrm{Cr}$ & $\mathrm{Mn}$ & $\mathrm{Cu}$ & $\mathrm{Zn}$ & $\mathrm{Se}$ \\
\hline \multirow[t]{5}{*}{ Yixingtan } & YXT-1 & 1785 & 747 & 32.48 & 6212 & 12890 & 0.07 & 15.93 & 8.06 & 69.71 & 2.73 \\
\hline & YXT-2 & 2379 & 742 & 72.03 & 9106 & 13750 & 0.23 & 15.28 & 8.54 & 66.67 & 2.32 \\
\hline & YXT-3 & 2024 & 756 & 68.22 & 7394 & 13210 & $0^{\mathrm{b}}$ & 12.79 & 7.82 & 68.79 & 2.54 \\
\hline & YXT-4 & 2454 & 703 & 29.45 & 9001 & 11570 & 0 & 8.99 & 7.53 & 74.48 & 1.67 \\
\hline & YXT-5 & 2208 & 676 & 59.95 & 8403 & 12130 & 0 & 10.73 & 7.22 & 75.82 & 1.67 \\
\hline \multicolumn{2}{|c|}{ Mean \pm SD } & $2170 \pm 272$ & $725 \pm 34$ & $52.43 \pm 20.10$ & $8023 \pm 1220$ & $12710 \pm 866$ & $0.06 \pm 0.10$ & $12.74 \pm 2.95$ & $7.83 \pm 0.50$ & $71.09 \pm 3.89$ & $2.19 \pm 0.49$ \\
\hline \multirow[t]{5}{*}{ Jiaoshan } & JS-1 & 2184 & 628 & 3 & 11500 & 9798 & 0 & 2.4 & 0.92 & 50.36 & 0.98 \\
\hline & JS-2 & 2259 & 660 & 3.38 & 11590 & 9167 & 0 & 2.93 & 1.31 & 46.95 & 0.78 \\
\hline & JS-3 & 2241 & 614 & 4.17 & 11750 & 8988 & 0 & 2.4 & 1.44 & 47.97 & 1.07 \\
\hline & JS-4 & 2243 & 651 & 12.96 & 11520 & 8545 & 0 & 2.64 & 1.27 & 49.19 & 1.05 \\
\hline & JS-5 & 2086 & 635 & 8.61 & 10830 & 9436 & 0 & 3.39 & 1.17 & 54.8 & 0.59 \\
\hline \multicolumn{2}{|c|}{ Mean \pm SD } & $2203 \pm 71$ & $638 \pm 18$ & $6.42 \pm 4.29$ & $11438 \pm 354$ & $9187 \pm 471$ & 0 & $2.75 \pm 0.42$ & $1.22 \pm 0.19$ & $49.85 \pm 3.05$ & $0.89 \pm 0.21$ \\
\hline \multirow[t]{5}{*}{ Pingtaishan } & PTS-1 & 2313 & 686 & 2.58 & 11280 & 9855 & 0 & 0 & 0.13 & 78.97 & 0.44 \\
\hline & PTS-2 & 2216 & 635 & 3.26 & 11030 & 10220 & 0 & 3.42 & 0.12 & 47.29 & 0.02 \\
\hline & PTS-3 & 2300 & 672 & 7.55 & 11500 & 11120 & 0 & 2.84 & 0.62 & 53.86 & 0 \\
\hline & PTS-4 & 2262 & 668 & 5.71 & 11100 & 10770 & 0 & 2.91 & 0.36 & 57.14 & 0.61 \\
\hline & PTS-5 & 2232 & 706 & 29.85 & 11070 & 11460 & 0 & 3.33 & 0.26 & 56.2 & 1.23 \\
\hline \multicolumn{2}{|c|}{ Mean \pm SD } & $2265 \pm 42$ & $673 \pm 26$ & $9.79 \pm 11.39$ & $11196 \pm 195$ & $10685 \pm 652$ & 0 & $2.50 \pm 1.42$ & $0.30 \pm 0.21$ & $58.69 \pm 11.97$ & $0.46 \pm 0.51$ \\
\hline \multirow[t]{5}{*}{ Sanshandao } & SSH-1 & 2242 & 587 & 0 & 7431 & 10270 & 0 & 1.84 & 0 & 48.67 & 1.45 \\
\hline & SSH-2 & 2376 & 578 & 0 & 7932 & 8868 & 0 & 1.54 & 0 & 45.54 & 1.7 \\
\hline & SSH-3 & 2091 & 596 & 1.08 & 7048 & 10860 & 0 & 3.51 & 0 & 60.93 & 2.07 \\
\hline & SSH-4 & 2017 & 566 & 0.66 & 6823 & 10400 & 0 & 2.35 & 0 & 51.51 & 1.18 \\
\hline & SSH-5 & 2218 & 584 & 0 & 7445 & 10050 & 0 & 1.42 & 0 & 50.65 & 1.54 \\
\hline \multicolumn{2}{|c|}{ Mean \pm SD } & $2189 \pm 139$ & $582 \pm 11$ & $0.35 \pm 0.50$ & $7336 \pm 425$ & $10090 \pm 744$ & 0 & $2.13 \pm 0.85$ & 0 & $51.46 \pm 5.77$ & $1.59 \pm 0.33$ \\
\hline
\end{tabular}

a The elements $\mathrm{Fe}, \mathrm{Co}, \mathrm{Ni}, \mathrm{As}, \mathrm{Mo}, \mathrm{Ag}, \mathrm{Tl}, \mathrm{Pb}$ were excluded because they were not detected in all P. chinensis samples.

${ }^{\mathrm{b}} 0$, not detected

Table 3. Matrix for statistical testing of element concentrations (mg/kg) in Protosalanx chinensis collected from four areas in Taihu Lake, China (Mann-Whitney U-test)

\begin{tabular}{|c|c|c|c|c|c|c|c|c|c|c|}
\hline Sampling area comparison & $\mathrm{Na}$ & $\mathrm{Mg}$ & $\mathrm{Al}$ & $\mathrm{K}$ & $\mathrm{Ca}$ & $\mathrm{Cr}$ & Mn & $\mathrm{Cu}$ & $\mathrm{Zn}$ & $\mathrm{Se}$ \\
\hline Yixingtan / Jiaoshan & ns & $* *$ & $* *$ & $* *$ & $* *$ & ns & $* *$ & $* *$ & $* *$ & $* *$ \\
\hline Yixingtan / Pingtaishan & ns & $*$ & $*$ & $* *$ & $* *$ & ns & $* *$ & $* *$ & ns & $* *$ \\
\hline Yixingtan / Sanshandao & ns & $* *$ & $* *$ & ns & $* *$ & ns & $* *$ & $* *$ & $* *$ & ns \\
\hline Jiaoshan / Pingtaishan & ns & $*$ & ns & ns & $* *$ & ns & ns & $* *$ & ns & ns \\
\hline Jiaoshan / Sanshandao & ns & $* *$ & $* *$ & $* *$ & ns & ns & ns & $* *$ & ns & $* *$ \\
\hline Pingtaishan / Sanshandao & ns & $* *$ & $* *$ & $* *$ & ns & ns & $\mathrm{ns}$ & $* *$ & ns & $*$ \\
\hline
\end{tabular}

*, $\mathrm{p}<0.05 ; * *, \mathrm{p}<0.01 ; \mathrm{ns}$, not significant

ciple component 1 (PC1), while $\mathrm{K}$ and Se offered the highest loadings for PC2. Moreover, all fish from Yixingtan, Jiaoshan, Sanshandao and Pingtaishan were always correctly classified by area using canonical discriminant analysis (CDA), using the same elements as in the PCA (Fig. 3). These results demonstrate that differentiation of specimens of $P$. chinensis from different areas of Taihu Lake is feasible by means of geographic elemental fingerprints. Moreover, the distinct fingerprints suggest that individuals and perhaps populations of $P$. chinensis from the four areas might be geographically isolated in the lake, as many salangids have poor swimming ability (Islam et al., 2006; Zhao et al., 2008).

To further evaluate the application of EFA for $P$. chinensis in inland lakes, a dendrogram from cluster analysis (CA) was derived by average linkage clustering 


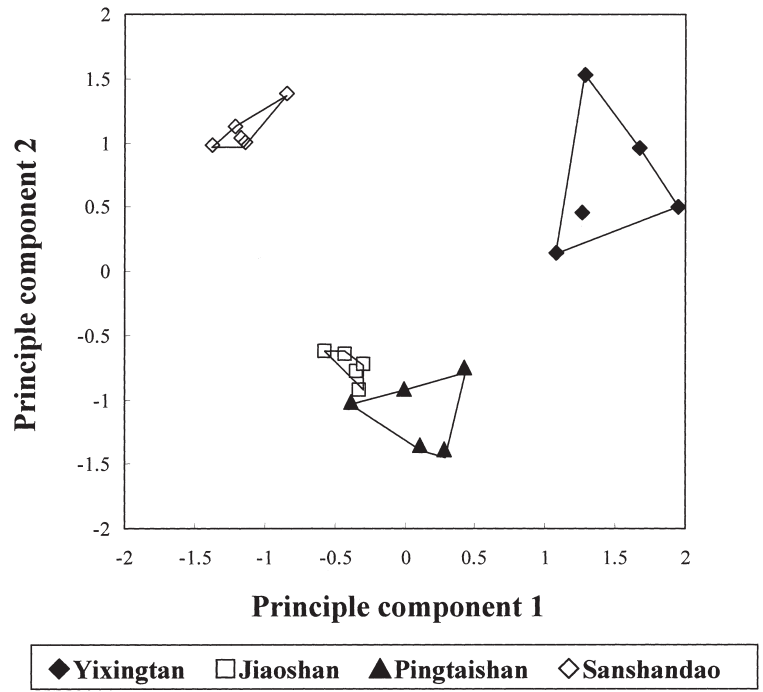

Fig. 2. Principal component analysis for chemical elements in large icefishes (Protosalanx chinensis) collected from Yixingtan, Jiaoshan, Pingtaishan and Sanshandao areas of Taihu Lake, China.

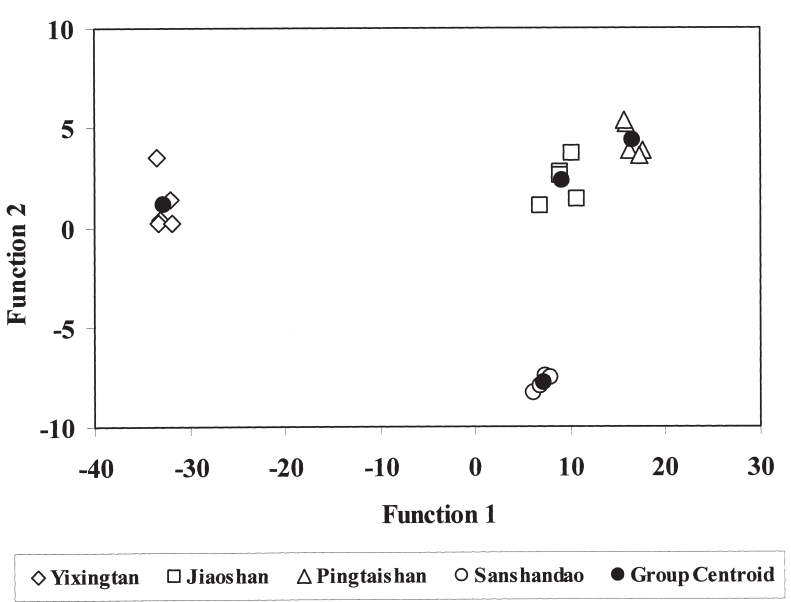

Fig. 3. Classification of large icefishes (Protosalanx chinensis) collected from different areas of Taihu Lake by means of canonical discriminant analysis on eight chemical elements: $\mathrm{Na}, \mathrm{Mg}, \mathrm{K}, \mathrm{Ca}, \mathrm{Mn}, \mathrm{Cu}, \mathrm{Zn}$ and $\mathrm{Se}$.

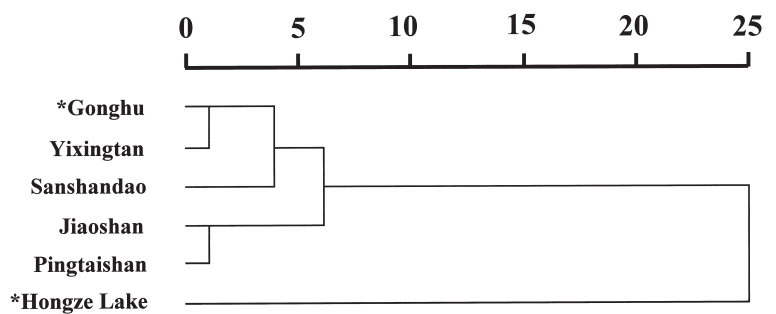

Fig. 4. The dendrogram for hierarchical cluster analysis of elemental fingerprints in large icefishes (Protosalanx chinensis) collected from Taihu Lake (Yixingtan, Jiaoshan, Pingtaishan Sanshandao and Gonghu areas) and Hongze Lake, China (*Data cited from Yang, Xu \& Liu, 2009). of the concentrations of $\mathrm{Na}, \mathrm{Mg}, \mathrm{K}, \mathrm{Ca}, \mathrm{Mn}, \mathrm{Cu}, \mathrm{Zn}$ and Se from the four areas of Taihu Lake and from Hongze Lake, $300 \mathrm{~km}$ away and the fourth largest lake in China (Yang et al., 2009). Taihu Lake and Hongze Lake belong to the Yangtze River and Huaihe River systems, respectively. The results of CA agree very well with those of PCA and CDA, as five distinct clusters were formed by fish from each of the five sites in Taihu Lake (Fig. 4). Furthermore, the greatest difference was in distinctive clustering of $P$. chinensis in Hongze Lake from all the icefishes from Taihu Lake. These findings strongly suggest that the inter-lake differences in geographic elemental fingerprints of $P$. chinensis are more significant than those from different areas within same lake, even though the latter also were significant.

\section{CONCLUSION}

The results of this study showed that $P$. chinensis, a locally important food resource around Taihu Lake, is a rich source of essential minerals (e.g., $\mathrm{Na}, \mathrm{Mg}, \mathrm{K}, \mathrm{Ca}$, $\mathrm{Zn}$ ), except for $\mathrm{Fe}$, and was not contaminated with potentially toxic $\mathrm{As}, \mathrm{Ag}$, and $\mathrm{Pb}$. Icefishes from the four localities could be consistently distinguished by elemental fingerprint analysis as well as from specimens of Hongze Lake. Furthermore, EFA is a very sensitive and accurate method to discern the geographic origin of specimens of $P$. chinensis, and our results suggest that EFA could be applied more broadly to identify the origin of other species or fishery products.

\section{ACKNOWLEDGMENTS}

This work was support by the Ministry of Science and Technology of China (6-115043) and and 973 project (2010CB429000). We thank greatly Professor Richard J. Neves and Dr. James Zheng for critically reading the manuscript and improving English.

\section{REFERENCES}

Branch, S., S. Burke, P. Evans, B. Fairman and C. S. J. Wollff Briche 2003 A preliminary study in determining the geographical origin of wheat using isotope ratio inductively coupled plasma mass spectrometry with ${ }^{13} \mathrm{C},{ }^{15} \mathrm{~N}$ mass spectrometry. J. Anal. Atom. Spect., 18: 17-22

Bury, N. and M. Grosell 2003 Iron acquisition by teleost fish. Comp. Biochem. Phys., 135: 97-105

Galgano, F., F. Favati, M. Caruso, T. Scarpa and A. Palma 2008 Analysis of trace elements in southern Italian wines and their classification according to provenance. LWT-Food Sci. Technol., 41: 1808-1815

Ishikawa, M. and K. Nakamura 1990 Trace elements in tissues and organs of an Antarctic icefish. Nucl. Instrum. Methods Phys. Res., 49: 220-224

Islam, M. S., M. Hibino, T. Ohta, K. Nakayama and M. Tanaka 2006 Environmental effect on diet, fecundity and condition of an endangered fish Neosalanx reganius (Osmeriformes) in the Chikugo Estuary, in the upper Ariake Bay, Japan. Aquat. Living Resour., 19: 59-68

Marcos, A., A. Fisher, G. Rea and S. J. Hill 1998 Preliminary study using trace element concentrations and a chemometrics approach to determine the geographical origin of tea. J. Anal. Atom. Spect., 13: 521-525 
Nalda, M. J. N., J. L. B. Yagüe, J. C. D. Calva and M. T. M. Gomez 2005 Classifying honeys from the Soria Province of Spain via multivariate analysis. Anal. Bioanal. Chem., 382: 311-319

Pillonel, L., R. Badertscher, P. Froidevaux, G. Haberhauer, S. Hölzl, P. Horn, A. Jakob, E. Pfammatter, U. Piantini, A. Rossmann, R. Tabacchi and J. O. Bosset 2003 Stable isotope ratios, major, trace and radioactive elements in emmental cheeses of different origins. LWT-Food Sci. Technol., 36: 615-623

Renou, J. P., G. Bielicki, C. Deponge, P. Gachon, D. Micol and P. Ritz 2004 Characterization of animal products according to geographic origin and feeding diet using nuclear magnetic resonance and isotope ratio mass spectrometry. Part II: beef meat. Food Chem., 86: 251-256

Terwilliger, N. B. 1998 Functional adaptations of oxygen-transport proteins. J. Exp. Biol., 201: 1085-1098

Watanabe, T., V. Kiron and S. Satoh 1997 Trace minerals in fish nutrition. Aquaculture, 151: 85-207

Xie, Y. and Xie, H. 1997 Classification, distribution, and population ecology of Salangidae fishes. Chinese J. Fish., 10: 11-19

Yamashita, Y., Y. Omura and E. Okazaki 2006 Distinct regional profiles of trace element content in muscle of Japanese eel Anguilla japonica from Japan, Taiwan, and China. Fish. Sci., 72: 1109-1113

Yamashita, M., A. Namikoshi, J. Iguchi, Y. Takashima, M. A. Hossain, T. Yabu and Y. Yamashita 2008 Molecular identification of species and the geographic origin of seafood. In Fisheries for Global Welfare and Environment, ed. by K. Tsukamoto, T. Kawamura, T. Takeuchi, T. D. Beard, Jr. and M. J. Kaiser, 5th World Fisheries Congress, Tokyo, Japan, pp. 297-306

Yang, J., X. Xu and H. Liu 2009 Bioaccumulation of elements in icefish Protosalanx hyalocranius from the Taihu Lake and Hongze Lake. Oceanol. et Limnol. Sin., 40: 201-207

Zhao, L., J. Zhang, Z. Liu, S. M. Funk, F. Wei, M. Xu and M. Li 2008 Complex population genetic and demographic history of the Salangid, Neosalanx taihuensis, based on cytochrome b sequences. BMC Evol. Biol., 8: 201 